\title{
PENGARUH LINGKUNGAN KERJA TERHADAP PRODUKTIVITAS PASCA PANEN PADI DI DESA LARA
}

\author{
Andi Haslindah ${ }^{1}$, Rizal Syarifuddin ${ }^{2}$, Alkarniyadi ${ }^{3}$, Alimuddin $^{4}$ \\ ${ }^{1,2}$ Program Studi Teknik Industri, Fakultas Teknik, Universitas Islam Makassar, \\ ${ }^{3,4}$ Program Studi Teknik industri, Fakultas Teknik, Universitas Islam Makassar, \\ Jl. Perintis Kemerdekaan km.9 No. 29 Makassar, Indonesia 90245 \\ Email: andihaslindah.dty@uim-makassar.ac.id,rizalsyarifuddin.dty@uim-makassar.ac.id \\ alimuddinnurdin305@gmail.com
}

\begin{abstract}
ABSTRAK
Lingkungan kerja adalah segala sesuatu yang ada di sekitar para pekerja dapat memepengaruhi dirinya dalam menjalankan tugas-tugas yang dibebankan. Tujuan penelitian ini adalah untuk mengetahui bagaimana pengaruh lingkungan kerja fisik terhadap produktivitas kerja pasca panen petani padi. Jenis penelitian ini mengunakan metode pengambilan data kualitatif dengan cara observasi, wawancara, dan pembagian kuesioner. identifikasi pengaruh lingkungan kerja terhadap produktivitas kerja dengan mengunakan analisis rigresi linear. Langkah selanjutnya setelah proses identifikasi adalah penilaian pengaruh masing-masing titik kajian. Berdasarkan hasil peneltian ini di ketahui nilai konstanta 26.556 dan koefesien regresi 1.321. Sehingga dapat disimpulkan bahwa lingkungan kerja berpengaruh positif terhadap produktivitas kerja.
\end{abstract}

Kata kunci: Lingkungan, produktivitas pasca panen

\begin{abstract}
The work environment is that anything around the worker may influence him in performing the imposed tasks. The goal of this study is to find out how the physical work environment of the rapid agricultural productivity in the rural lara district of northern luwu. This kind of study USES qualitative data retrieval methods in observation, interviews, and questionnaire division. This research was carried out in the lara county of northern luwu. Identifying work environment's effects on job productivity by using linear regression analysis. The next step after the identification process is an assessment of each impact point. According to this study the value of the 26,556 constant and regression coefficient 1321 . So to speak, the work environment has a positive effect on productivity.
\end{abstract}

Keyword: Environment, post-hervest productivity

\section{PENDAHULUAN}

Manejemen sumber daya manusia adalah suatu proses menangani berbagai masalah pada ruang lingkup karyawan, pegawai, buruh, manajer, dan tenaga kerja lainya untuk dapat menunjang aktivitas organisasi atau perusahan demi mencapai tujuan yang telah di tentukan. Dalam suatu perusahan,komponen yang sangat untuk mendorong produksi dan tujuan perusahaan ialah sumber daya manusia.

Produktivitas adalah perbandingan antara hasil yang dicapai (output) dengan keseluruhan sumber daya yang digunakan (input). Produktivitas memiliki 
dua dimensi, yaitu efisiensi dan efektivitas. Efektivitas mengarah pada pencapaian

kerja yang maksimal melalui pencapaian target sesuai dengan kualitas, kuantitas, dan waktu. Efisiensi berkaitan dengan upaya membandingkan input dengan realisasi penggunaannya atau bagaimana pekerjaan tersebut dilaksanakan (Husein, 2005).

Lingkungan kerja adalah segala sesuatu yang ada di sekitar para pekerja dapat mempengaruhi dirinya dalam menjalankan tugas-tugas yang dibebankan. Misalnya kebersihan, musik dan lainlain. (Nitisemito, 2002). Menurut Alex S Nitisemito (2002) faktor-faktor yang berhubungan dan berpengaruh terhadap produktivitas kerja secara garis besar dapat dibagi dalam tiga bagian yaitu dari lingkungan kerja fisik sekitarnya seperti suhu, kelembapan, penerangan, kebisingan dan lain sebagainya. Menurut Moekijat (2004), faktor-faktor yang penting dari lingkungan kerja fisik dalam kebanyakan kantor adalah penerangan, warna, udara, musik, dan suara. Sedangkan menurut Siagian (2009) kondisi yang menyenangkan sangat berperan dalam pemeliharaan kesehatan dan keselamatan kerja karena akan meningkatkan produktivitas kerja. Secara umum, pasca panen dapat diartikan sebagai tindakan meliputi pemetikan hasil, pembersihan lahan, pengangkutan hasil, penyimpanan hingga pengemasan. Tujuan utama dari pasca panen adalah guna menghasilkan panen sesuai standar nasioal yang berlaku. Tindakan pasca panen ini bertujuan untuk meminimalisir hasil yang kurang memuaskan pada periode tanam selanjutnya. Panen merupakan tindakan akhir dari sebuah proses penamaman. Penelitian sama juga dilakukan oleh Teguh Ariefiantoro (2012) mengatakan bahwa variabel lingkungan kerja fisik mempunyai pengaruh yang signifikan terhadap produktivitas kerja karyawan Tujuan penelitian ini adalah untuk mengetahui bagaimana pengaruh lingkungan kerja fisik terhadap produktivitas kerja pasca panen petani padi di desa lara kabupaten luwu utara.

Upaya untuk meningkatkan produktivitas juga dilakukan dengan pemberdayaan karyawan,sebagai mana pendapat Kahrer, dkk (2015). Menurut famade dkk (2016) menjelaskan bahwa produktivitas akan timbul ketika terdapat kenaikan output seiring dengan peneurunan input atau dengan output yang sama tetapi dengan input yang menurun.

\section{METODE PENELITIAN}

Penelitian ini mengunakan metode pengambilan data kualitatif dan untuk metode pembuktian hipotesis peneliti mengunakan analisis regresi linear sederhana

\section{Alat, Bahan dan Metode :}

Alat utama yang digunakan dalam penelitian ini adalah laptop, pulpen, dan kertas. Bahan yang digunakan dalam pengolahan data adalah Microsoft word, misrosoft excel, dan IBM SPSS. Metode analisi yang digunakan dalam penelitian ini adalah regresi linear sederhana.

\section{HASIL DAN PEMBAHASAN:}

\section{Uji validitas}

Unutuk mengetahui apakah data tersebut valid aka dilakukan uji validitas pada data kusioner seperti pada tabel dibawa ini

Tabel 1. Uji validitas

\begin{tabular}{|c|c|c|c|c|}
\hline $\begin{array}{c}\text { Kode } \\
\text { bertanyaan }\end{array}$ & Korelasi & Sig & $\begin{array}{c}\text { Batas minimal } \\
\text { korelasi }\end{array}$ & Keputusan \\
\hline r. 1 & 0,488 & 0,06 & 0,30 & Valid \\
\hline r. 2 & 0,479 & 0,07 & 0,30 & Valid \\
\hline r.3 & 0,516 & 0,04 & 0,30 & Valid \\
\hline r. 4 & 0,449 & 0,13 & 0,30 & Valid \\
\hline r. 5 & 0,516 & 0,04 & 0,30 & Valid \\
\hline r.6 & 0,402 & 0,27 & 0,30 & Valid \\
\hline r. 7 & 0,449 & 0,13 & 0,30 & Valid \\
\hline r. 8 & 0,479 & 0,07 & 0,30 & Valid \\
\hline r.9 & 0,449 & 0,13 & 0,30 & Valid \\
\hline r. 10 & 0,516 & 0,04 & 0,30 & Valid \\
\hline
\end{tabular}

Sumber spss 25

Nilai $r$ hitung adalah 0,604 dibandingkan dengan nilai $r$ tabel atau nilai product moment yaitu sebesar $(n-2)=28$ untuk taraf kesalahan 5\%. Karena nilai $r$ hitung > nilai $r$ product moment yaitu 0,604 > 0,05 maka pernyataan tersebut valid. 


\section{Uji reablitas}

Unutuk mengetahui apakah data tersebut reliabel maka dilakukan uji reabilits pada data kusioner seperti pada tabel dibawa ini

\section{Tabel 2. Uji reabilitas}

\begin{tabular}{|c|c|c|c|}
\hline \multicolumn{4}{|c|}{ Case Processing Summary } \\
\hline & & $\mathrm{N}$ & $\%$ \\
\hline \multirow[t]{3}{*}{ Cases } & Valid & 30 & 100.0 \\
\hline & Excludeda & 0 & .0 \\
\hline & Total & 30 & 100.0 \\
\hline
\end{tabular}

\begin{tabular}{|r|r|}
\hline \multicolumn{2}{|c|}{ Reliability Statistics } \\
\hline $\begin{array}{c}\text { Cronbach's } \\
\text { Alpha }\end{array}$ & N of Items \\
\hline 330 & 10 \\
\hline
\end{tabular}

\begin{tabular}{|c|c|c|c|c|}
\hline \multicolumn{5}{|c|}{ Item-Total Statistics } \\
\hline & $\begin{array}{l}\text { Scale Mean if } \\
\text { Item Deleted }\end{array}$ & \begin{tabular}{c|c} 
Scale \\
Variance if \\
Item Deleted
\end{tabular} & \begin{tabular}{c|} 
Corrected \\
Item-Total \\
Correlation \\
\end{tabular} & $\begin{array}{c}\text { Cronbach's } \\
\text { Alpha if Item } \\
\text { Deleted }\end{array}$ \\
\hline r_1 & 28.97 & 9.137 & .184 & .273 \\
\hline$r_{2} 2$ & 29.47 & 11.016 & -.061 & .392 \\
\hline$r+3$ & 28.47 & 9.361 & .303 & .229 \\
\hline r_ 4 & 29.83 & 9.661 & .207 & .268 \\
\hline$r_{-} 5$ & 29.47 & 10.257 & .086 & .322 \\
\hline r.6 & 28.60 & 10.179 & .216 & .276 \\
\hline$r+7$ & 28.63 & 11.068 & .059 & .328 \\
\hline r_8 & 30.27 & 9.995 & .119 & .307 \\
\hline r_o & 30.10 & 10.231 & .055 & .339 \\
\hline$r-10$ & 30.80 & 9.890 & .104 & .316 \\
\hline
\end{tabular}

Sumber spss 25

Dari hasil uji reability dengan mengunakan Software SPSS 25. Didapatkan hasil Cronbach's Alpha sebesar 0,330. Hal ini dapat dikategorikan kurang baik karena na reabilitas kurang dari 0,60.

\section{Analisis regeresi linear sederhana}

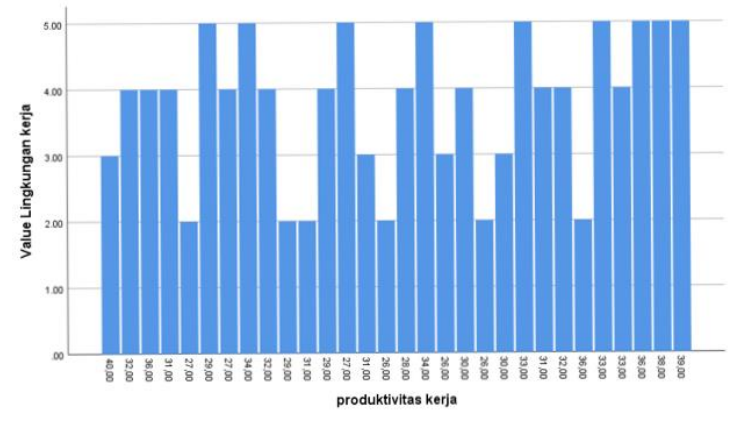

Gambar 1. Garafik regresi

Setelah produktivitas dan lingkungan kerja ditemukan, maka persamaan regresi linear dapat disusun. Persamaan produktivitas dan lingkungan adalah sebagai berikut:

$\mathrm{Y}=28.206+3.402 \mathrm{x}$

Persamaan regresi yang telah ditemukan dapat digunakan untuk memperdiksi bagaimana dala variabel dependent akan terjadi apabila variabel independent ditetapkan. Misalnya nilai rata rata produktivitas kerja adalah

$\mathrm{Y}=28.206+3.402=31.608$

Analisis regresi linear sederhana juga mengunakan untuk mengetahui pengaruh lingkungan kerja terhadap produktivitas kerja pasca panen berdasarkan perhitingan dan bantuan Spss 25 for windows diperoleh hasil sebgai berikut:

\section{Tabel 3. Regresi linear sedehana}

\begin{tabular}{|c|c|c|c|c|c|c|}
\hline \multirow{2}{*}{\multicolumn{2}{|c|}{ Model }} & \multicolumn{2}{|c|}{$\begin{array}{l}\text { Unstandardized } \\
\text { Coefficients }\end{array}$} & \multirow{2}{*}{\begin{tabular}{|c|}
$\begin{array}{c}\text { Standardized } \\
\text { Coefficients }\end{array}$ \\
Beta \\
\end{tabular}} & \multirow[b]{2}{*}{$t$} & \multirow[b]{2}{*}{ Sig. } \\
\hline & & B & Std. Error & & & \\
\hline \multirow[t]{2}{*}{1} & (Constant) & 26.556 & 2.421 & & 10.969 & .000 \\
\hline & $\begin{array}{l}\text { lingkungan } \\
\text { keria }\end{array}$ & 1.321 & .618 & .375 & 2.140 & .041 \\
\hline
\end{tabular}

Sumber spss 25

Berdasarkan tabel diatas dibuatkan persamaan sebagai berikut:

Produktivitas kerja $(\mathrm{Y})=26.556+1.321$ Lingkungan kerja $(\mathrm{X})$

Konstanta $=26,556$

Hal ini menunjukan bahwa faktor lingungan kerja bernilai nol, maka produktivitas kerja petani sebesar 26,556

Koefesien regresi $=1,321$

Bahwa setiap variabel meningkat satu kali, hal ini menunjukan peningkatan atas lingkungan 
kerja akan meningkat sebesar 1.321 satu satuan. Karena tabel diatas menunjukan koefesien lingkungan kerja $=1.321$ menunjukan koefesien lingkungan tanda positif dari koefesien ini mengendifikasikan bahwa pengaruh lingkungan kerja terhadap produktivitas adalah positif. Hal ini dikuatkan fakta sig $\alpha<(0,41)$. Maka hipotesis berbunyi lingkungan kerja berpengaruh positif terhadap produktivitas kerja pasca panen. Dengan demikian jika lingkungan kerja baik maka akan mengakibatkan produktivitas kerja tinggi, sebaliknya jika lingkungan kerja buruk akan mengakibatkan produktivitas kerja petani buruk. Oleh karena itu dapat disimpulkan bahwa lingkungan kerja petani di luwu utara bepengaruh penting terhadap produktivitas kerja pasca panen.

$$
\begin{gathered}
Y=a+b x \\
Y=26,556+1,321
\end{gathered}
$$

Koefesien nilai konstanta adalah 26,556 hal ini berarti jika variabel x ( lingkungan kerja ) bernilai 1, maka variabel y (produktivitas kerja) bernilai 26,556. Selanjutnya koefesien regresi linear variabel $\mathrm{x}$ (lingkungan kerja) sebesar 1,321 memeiliki arah positif hal ini berarti setiap peningkatan satu poin pada lingkungan kerja meningkatkan produktivitas kerja sebesar 1,321.

Penelitian terdahulu tentang pengaruh Lingkungan Kerja Terhadap Peningkatan Produktivitas Karyawan Pada CV. Codok Wajak Malang (2009). Dari hasil analisis data menunjukkan bahwa terdapat pengaruh yang signifikan antara variabel bebas yaitu lingkungan kerja terhadap variabel terikat yaitu produktivitas karyawan, hal ini ditunjukkan dengan nilai terhitung 8,092 t tabel 1,69 dan nilai signifikannya 0.05 . Dari hasil penelitian diperoleh bahwa t hitung : 8,092 dan t tabel : 1.69 oleh karena $t$ hitung $>\mathrm{t}$ tabel maka Ho ditolak dan Ha di terima. Pada level signifikan 0,05 sehingga sehingga variabel lingkungan kerja memiliki pengaruh signifikan terhadap produktivitas karyawan

\section{KESIMPULAN:}

Dari hasil penelitian dapat disimpulkan bahwa bahwa lingkungan kerja berpengaruh positif terhadap produktivitas kerja pasca panen. Dengan demikian jika lingkungan kerja baik maka akan mengakibatkan produktivitas kerja baik.

\section{UCAPAN TERIMA KASIH:}

Pertama-tama kami ucapkan terima kasih banyak kepada kepala desa yang telah memberikan kami kesempatan untuk melakukan penelitian ini. Dan tak lupa pula saya ucapkan terima kasih terima kasih kepada pembimbing dan segenap orang-Orang yang terlibat dalam dalam penelitian kami.

\section{DAFTAR PUSTAKA:}

Andi Haslindah, Muhammad Fadhli, Nursanti, (2018), Analisis Pengendalian Kualitas Produk Markisa Tongkonan Dengan Menggunakan Metode Statistic Quality Control (SQC) Pada IKM Palawa CO, ILTEK,Volume 13, Nomor 25, April 2018,ISSN : 1907-0772, hal. 1833 1836, Fakultas Terknik Univ. Islam Makassar.

Alex S Nitisemito. (2002). Faktor-faktor yang berhubungan yang berpengaruh terhadap produktivitas kerja. Jurnal Manajemen.

Famade, dkk (2016). An assessment of various strategies in enhancing workers productive capacity in negeria's tertiary institutions. African Education Recearch journal.

Husein Umar. 2008. Metode Riset Perilaku Konsumen jasa Jakarta: Ghalia Indonesia.

Kahrer, dkk (2011). Anchieving competitive advantage through empowering employes: empirical study. Far East Journal of Psychology and Business 3(2), 26 - 37

Moekijat. 2004. Tata Laksana Kantor. Bandung: Mandar Maju.

Nitisemito, alex S. 202. Manajemen sumber manausia, Jakarta Ghalia.

Siagian, P. Sondang. 2009. Kiat Meningkatkan Produktivitas Kerja. Jakarta. Rineka Cipta Teguh, Ariefiantoro. 2012. Analisis Pengaruh Kepemimpinan, Kepuasan Kerja dan Lingkungan Kerja Fisik Terhadap Produktivitas Kerja Karyawan : Studi Kasus Karyawan Bagian Produksi PT. Sango Ceramic Indonesia.

Suradi, (2017), Pengaruh Kecelakaan Kerja Terhadap Produktivitas Kerja Karyawan PT. Maruki International Indonesia, Volume 12, Nomor 23, April 2017, hal. 1692 
- 1695, Fakultas Terknik Univ. Islam Makassar. 